\title{
Rape embryogenesis. III. Embryo development in time
}

\author{
TERESA TYKARSKA
}

Laboratory of Electron Microscopy, Institute of Botany, Warsaw University, ul. Krakowskie Przedmieście 26/28, 00-325 Warszawa, Poland

(Received: February 27, 1980)

\begin{abstract}
It was found that the growth curve of the rape embryo axis is of triple sigmoid type. Embryo growth occurs in 3 phases corresponding to 3 different periods of development. Phase I includes growth of the apical cell up to its division into two layers of octants. Phase II comprises the increase of the spherical proembryo to the change of its symmetry from radial to bilateral. Phase III includes, growth of the embryo from the heart stage up to the end of embryogenesis. In each phase the relative growth rate increases drastically and then diminishes. The differences in growth intensity during the same phase are several-fold. The growth intensity maximum of the embryo axis occurs in phase II. The phasic growth intensity maxima occur: in phase I during apical cell elongation, before its division, and in phases II and III in the periods of cell division growth in globular and torpedo-shaped embryos.
\end{abstract}

\section{INTRODUCTION}

The development of the rape embryo has been described in two preceding publications ( $\mathrm{Tyk}$ a rska, 1976, 1979). The present paper is a supplement to developmental anatomical investigations. It concerns observation of the occurrence of the previously distinguished development stages in the successive days after anthesis. Owing to this, it was possible to establish the mean age of the embryo in each stage. On the basis of data on the embryo length in the successive stages from the previous papers, the growth curves of the embryo could be plotted and analysed.

The mature rape embryo consists of an arched axis and two fleshy sotyledons surrounding it on both sides, overlapping one another.

The axis is built of two cell layers: $l$ and $l^{\prime}$, which defferentiate in the proembryo during division of the quadrants and octants. The upper 
layer $l$ forms the epicotyledonar part with the shoot apical meristem and cotyledons. Layer $l^{\prime}$ develops to the hypocotyl and root. Between layer $l^{\prime}$ and the columella of the root cap there lies a layer of connecting cells - iec. The whole embryo thus arises, not only from the iec layer and the central part of the root cap, but from the apical cell (ca) of the two-cell proembryo. The connecting layer and collumella arise from the hypophysis, the only derivative of the basal cell (cb) which becomes a component of the body of the embryo proper.

\section{MATERIAL AND METHODS}

The observations were conducted for 40 days from the end of May to the beginning of July 1976 on rape plants sown in the experimental garden of the University. More than 30 plants were chosen and marked. For each plant a diagram of the inflorescence was prepared and every or every second day the unfolding, wilting and petal shedding'flowers were marked on it as well as young siliques. The defects due to young silique drying were also marked. Owing to this system each silique had its pedigree. Every day several siliques of different ages were collected randomly from various plants to determine the stage of - development. From each silique at least 3 embryos were prepared out: from the developing ovules in the top, the middle and the bottom parts of the silique. The youngest embryos up to the heart stage were pressed out with a dissecting needle from embryos placed in water on a slide, covered with a coverslip and inspected in the microscope. The torpedo and maturation stages were prepared out under a magnifying glass, older ones without magnification. A total of 1468 embryos in various developmental stages were examined. The material was classifield to the following groups (in parentheses the abbreviations used in the Tables):

1. proembryo with one-cell apical part ca (1c.-ca),

2. proembryo with two-cell apical part ca (2c.-ca),

3. quadrant stage (quadr.),

4. octant stage (oct.),

5. 16-celled proembryo with differentiated dermatogen in layers $l$ and $l^{\prime}$ (derm.),

6. first division of dermatogen or inner cells layer $l$ (I div.),

7. proembryo with differentiated periblem and plerome mother cells in layer $l^{\prime}$ (per.-pl.),

8. younger globular embryo (glob. 1),

9. older globular embryo (glob. 2),

10. transition stage (trans.),

11. younger heart stage (heart 1), 
12. older heart stage (heart 2),

13. younger torpedo stage - heart-torpedo embryos (torp. 1),

14. older torpedo stage - embryo torpedo-shaped with somewhat bent cotyledons and axis, corresponding to early "walking stick" stage (R i j ven, 1952) (torp. 2),

15. inverted U-shaped embryo (inv. U),

16. almost fully developed embryos corresponding to group "end of embryogenesis" (Tykarska, 1979). Almost fully grown embryos with well developed large cotyledons of the same length as the embryo axis, but more delicate, with a thinner and less bent axis than in older embryos (alm. dev.),

17. full grown maturing embryos, prepared out from still intensively green seeds, easily detachable from seed coat (green a),

18. maturing ambryos from pale-green seeds filling seed coat tightly (green b),

19. maturing embryos from yellowish-green seeds (yell.-green),

20. maturing embryos from brownish-green seeds (br.-green),

21. maturing embryos from brown seeds (brown),

22. mature embryos from black seeds (black).

Meteorological data concerning the University premises supplied by the Department of Meteorology and Climatology of the Warsaw University are presented in Fig. 1.

The meteorological conditions during the experiment were highly variable. Therefore, for a detailed analysis of embryo growth, results of observations were chosen performed on embryos developing under the most uniform meteorological conditions, that is on embryos from flowers which opened between June 20 and 25. These data are listed in Table 3. This table gives for each age of the embryo $(y)$ (i.e. for the successive days after anthesis) the number and frequency of occurrence $(\%)$ of the successive developmental stages of the embryo, and for each stage the percentual proportion of its occurrence in the successive days $(x)$. This gave a basis for calculating for each stage the mean age of the embryo $T$ according to the formula $T=\frac{x y}{100}$ days, where $x$ denotes the percentual participation of the given stage in the successive days of its occurrence and $y$ the embryo age on these days.

Taking into account these data and the mean lengths and widths of the embryo axis (Table 4) - calculated in the previous papers (Ty$\mathrm{k}$ a r s a 1976,1979$)$, the growth curves of the rape embryo axis was plotted in arithmetic (Fig. 3) and logarithmic scale (Fig. 4). 


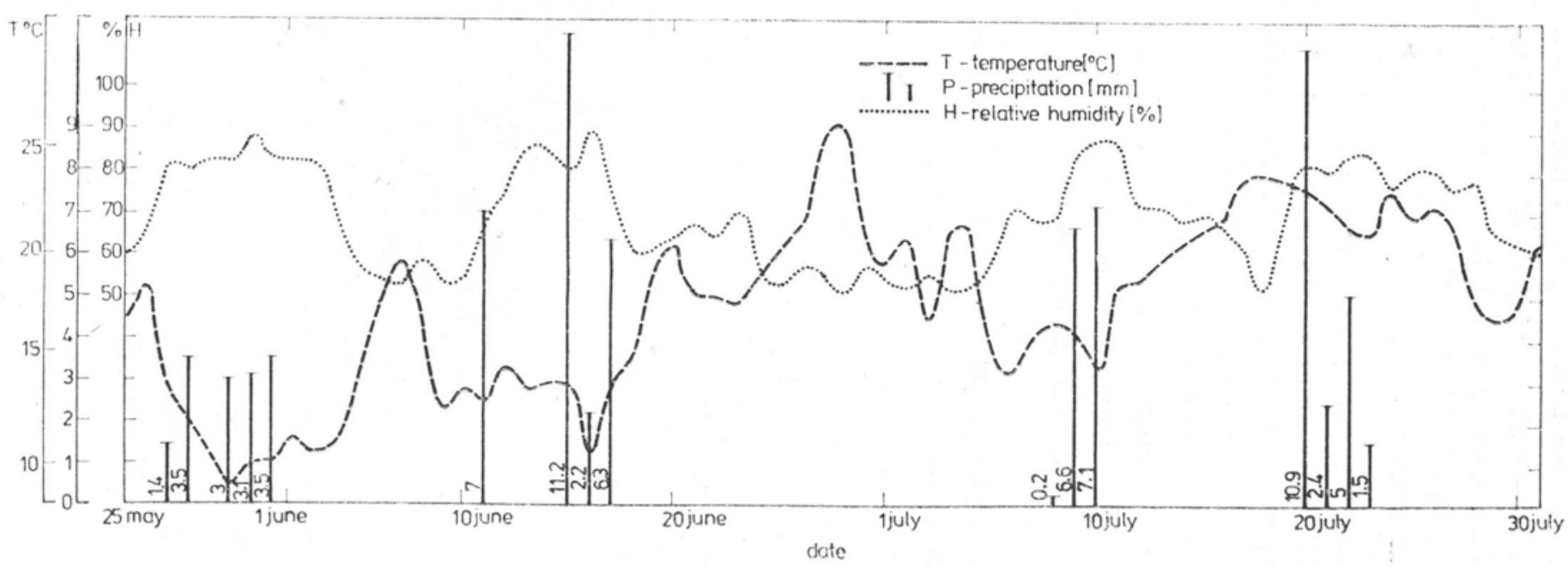

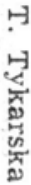

Fig. 1. Mean diurnal temperatures $\left({ }^{\circ} \mathrm{C}\right)$, relative humidity $(\% / 0)$ and precipitation $(\mathrm{mm})$ in the period May 25 to July 31,1976 at the Warsaw University 


\begin{tabular}{|c|c|c|c|c|c|c|c|c|c|c|c|c|c|c|c|c|c|c|c|c|c|c|c|}
\hline \multicolumn{2}{|c|}{ Stadium } & \multirow[t]{2}{*}{ ic.-ca } & \multirow[t]{2}{*}{ 2c.-ca } & \multirow[t]{2}{*}{ quedr. } & \multirow[t]{2}{*}{ octant } & \multirow[t]{2}{*}{ derm. } & \multirow[t]{2}{*}{ I div. } & \multirow[t]{2}{*}{ per.-pl. } & \multirow[t]{2}{*}{$\underset{1}{\text { glob. }}$} & \multirow[t]{2}{*}{$\underset{2}{\text { glob. }}$} & \multirow[t]{2}{*}{ trans. } & \multirow[t]{2}{*}{$\begin{array}{c}\text { heart } \\
1\end{array}$} & \multirow[t]{2}{*}{$\begin{array}{c}\text { heart } \\
2\end{array}$} & \multirow[t]{2}{*}{ torp. } & \multirow[t]{2}{*}{$\begin{array}{c}\text { torp. } \\
2\end{array}$} & \multirow[t]{2}{*}{ inv. U } & \multirow[t]{2}{*}{$\begin{array}{l}\text { alm. } \\
\text { dev. }\end{array}$} & \multirow[t]{2}{*}{$\begin{array}{c}\text { green } \\
a\end{array}$} & \multirow[t]{2}{*}{$\underset{b}{\text { green }}$} & \multirow[t]{2}{*}{$\begin{array}{c}\text { yel.- } \\
\text { green }\end{array}$} & \multirow[t]{2}{*}{$\begin{array}{c}\text { br.- } \\
\text { green }\end{array}$} & brown & black \\
\hline & 1 & & & & & & & & & & & & & & & & & & & & & & \\
\hline & 2 & $2 / 29.5$ & $1 / 1.7$ & & & & & & & & & & & & & & & & & & & & \\
\hline & 3 & $1 / 23.6$ & $1 / 27.6$ & \begin{tabular}{|l|}
$1 / 25.6$ \\
$3 / 27.6$ \\
$3 / 1.7$
\end{tabular} & $4 / 25.6$ & & & & & & & & & & & & & & & & & & \\
\hline & 4 & & & $1 / 26.6$ & $11 / 24.6$ & & & & & & & & & & & & & & & & & & \\
\hline & 5 & & $1 / 21.6$ & $1 / 22.6$ & $\begin{array}{l}2 / 21.6 \\
2 / 22.6\end{array}$ & $\begin{array}{l}2 / 22.6 \\
2 / 23.6 \\
4 / 25.6\end{array}$ & $\begin{array}{l}1 / 22.6 \\
1 / 23.6 \\
2 / 25.6\end{array}$ & & & & & & & & & & & & & & & & \\
\hline & 6 & & & $1 / 21.6$ & $\begin{array}{l}1 / 206 \\
1 / 21.6\end{array}$ & \begin{tabular}{|l|}
$1 / 21.5$ \\
$1 / 22.6$
\end{tabular} & $\begin{array}{l}1 / 20.6 \\
1 / 8.6 \\
2 / 24.6\end{array}$ & \begin{tabular}{l|}
$8 / 8.6$ \\
$1 / 20.6$ \\
$2 / 21.6$ \\
$1 / 22.6$ \\
$4 / 24.6$
\end{tabular} & $\begin{array}{l}1 / 21.6 \\
1 / 22.6 \\
3 / 24.6\end{array}$ & $1 / 8.6$ & & & & & & & & & & & & & \\
\hline & 7 & & & & & & & $\begin{array}{l}1 / 19.6 \\
1 / 23.6\end{array}$ & $\begin{array}{l}2 / 19.6 \\
1 / 21.6 \\
3 / 21.6 \\
\end{array}$ & $\begin{array}{l}2 / 21.6 \\
1 / 22.6 \\
5 / 23.6 \\
\end{array}$ & \begin{tabular}{|l|}
$2 / 22.6$ \\
$6 / 23.6$
\end{tabular} & & & & & & & & & & & & \\
\hline & 8 & & & & & & $\begin{array}{l}1 / 15.6 \\
1 / 18.6\end{array}$ & $3 / 15.6$ & $\begin{array}{l}2 / 15.6 \\
5 / 18.6 \\
3 / 30.6\end{array}$ & $\begin{array}{l}2 / 26.6 \\
3 / 30.6\end{array}$ & \begin{tabular}{|l|}
$3 / 21.6$ \\
$1 / 26.6$
\end{tabular} & $3 / 22.6$ & & & & & & & & & & & \\
\hline & 9 & & & & & & & & $1 / 15.6$ & $\begin{array}{l}2 / 15.6 \\
1 / 21.6 \\
1 / 29.6 \\
\end{array}$ & \begin{tabular}{|l|}
$2 / 26.6$ \\
$1 / 21.6$ \\
$2 / 29.6$ \\
\end{tabular} & \begin{tabular}{|l|}
$1 / 20.6$ \\
$1 / 21.6$ \\
$3 / 25.6$ \\
\end{tabular} & & & & & & & & & & & \\
\hline & 10 & & & & & & & & $\begin{array}{l}2 / 27.6 \\
1 / 28.6\end{array}$ & $\begin{array}{l}4 / 27.6 \\
2 / 28.6 \\
3 / 13.6\end{array}$ & \begin{tabular}{|l|}
$2 / 27.6$ \\
$7 / 28.6$
\end{tabular} & $\begin{array}{l}3 / 19.6 \\
3 / 20.6 \\
4 / 24.6 \\
4 / 27.6 \\
6 / 28.6\end{array}$ & $2 / 24.6$ & & & & & & & & & & \\
\hline & 11 & & & & & & & & & $2 / 12.6$ & $\begin{array}{l}4 / 12.6 \\
3 / 27.6\end{array}$ & $\begin{array}{l}3 / 18.6 \\
6 / 19.6 \\
1 / 27.6\end{array}$ & $\begin{array}{l}3 / 23.6 \\
4 / 27.6\end{array}$ & $2 / 27.6$ & & & & & & & & & \\
\hline & 12 & & & & & & & & & $\begin{array}{l}2 / 11.6 \\
1 / 14.6 \\
1 / 15.6\end{array}$ & \begin{tabular}{|l|}
$1 / 11.6$ \\
$2 / 14.6$ \\
$1 / 15.6$
\end{tabular} & $\begin{array}{l}1 / 15.6 \\
1 / 17.6 \\
4 / 18.6 \\
1 / 26.6\end{array}$ & $\begin{array}{l}2 / 17.6 \\
2 / 18.6 \\
13 / 26.6\end{array}$ & $6 / 26.6$ & $2 / 26.6$ & & & & & & & & \\
\hline & 13 & & & & & & & & & & & $3 / 14.6$ & \begin{tabular}{|l|}
$7 / 24.6$ \\
$7 / 25.6$
\end{tabular} & $\begin{array}{l}5 / 24.6 \\
12 / 25.6\end{array}$ & $3 / 25.6$ & & & & & & & & \\
\hline & 14 & & & & & & & & & & & $\begin{array}{l}3 / 10.6 \\
3 / 13.6 \\
1 / 24.6\end{array}$ & $\begin{array}{l}1 / 18.6 \\
1 / 23.6 \\
5 / 24.6\end{array}$ & \begin{tabular}{|c|}
$2 / 18.6$ \\
$10 / 23.6$ \\
$11 / 24.6$
\end{tabular} & \begin{tabular}{|l|}
$1 / 23.6$ \\
$6 / 24.6$ \\
\end{tabular} & & & & & & & & \\
\hline & 15 & & & & & & & & & & & & $2 / 11.6$ & $\begin{array}{l}1 / 11.6 \\
2 / 19.6 \\
1 / 23.6\end{array}$ & \begin{tabular}{l|}
$7 / 19.6$ \\
$9 / 23.6$
\end{tabular} & $8 / 23.6$ & & & & & & & \\
\hline & 16 & & & & & & & & & & & & \begin{tabular}{|l|}
$1 / 12.6$ \\
$2 / 18.6$
\end{tabular} & \begin{tabular}{|l|}
$3 / 9.6$ \\
$3 / 10.6$ \\
$2 / 12.6$ \\
$1 / 18.6$ \\
$3 / 21.6$ \\
\end{tabular} & \begin{tabular}{|l|}
$3 / 18.6$ \\
$9 / 21.6$
\end{tabular} & $3 / 22.6$ & & & & & & & \\
\hline & 17 & & & & & & & & & & & & & $3 / 8.6$ & $5 / 20.6$ & \begin{tabular}{|l|}
$4 / 20.6$ \\
$6 / 21.6$
\end{tabular} & & & & & & & \\
\hline & 18 & & & & & & & & & & & & & & $\begin{array}{l}3 / 14.6 \\
1 / 19.6\end{array}$ & \begin{tabular}{|l|}
$3 / 16.6$ \\
$5 / 19.6$ \\
$6 / 20.6$ \\
\end{tabular} & & & & & & & \\
\hline & 19 & & & & & & & & & & & & $1 / 7.6$ & \begin{tabular}{|l|}
$3 / 7.6$ \\
$1 / 9.6$ \\
\end{tabular} & \begin{tabular}{|l|}
$2 / 7.6$ \\
$5 / 9.6$ \\
\end{tabular} & $\begin{array}{l}6 / 18.6 \\
6 / 19.6 \\
\end{array}$ & & & & & & & \\
\hline b & 20 & & & & & & & & & & & & & \begin{tabular}{|l|}
$1 / 6.6$ \\
$2 / 7.6$ \\
$1 / 8.6$ \\
\end{tabular} & \begin{tabular}{|l|}
$2 / 6.6$ \\
$4 / 7.6$ \\
$5 / 8.6$ \\
\end{tabular} & $\begin{array}{l}3 / 12.6 \\
9 / 14.6 \\
7 / 18.6 \\
\end{array}$ & $14 / 18.6$ & & & & & & \\
\hline 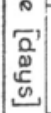 & 21 & & & & & & & & & & & & & $1 / 3.7$ & \begin{tabular}{|l|}
$3 / 2.6$ \\
$2 / 3.6$ \\
$6 / 7.6$
\end{tabular} & \begin{tabular}{|l|}
$9 / 17.6$ \\
$3 / 7.6$ \\
$3 / 11.6$ \\
$3 / 13.6$
\end{tabular} & 9/17.6 & & & & & & \\
\hline & 22 & & & & & & & & & & & & & & $\begin{array}{l}3 / 20.6 \\
4 / 6.6\end{array}$ & $\begin{array}{l}2 / 6.6 \\
5 / 10.6 \\
3 / 12.6\end{array}$ & $\begin{array}{l}3 / 12.6 \\
1 / 10.6 \\
6 / 16.6\end{array}$ & & & & & & \\
\hline & 23 & & & & & & & & & & & & & $\begin{array}{c}3 / 9.6 \\
\text {. }\end{array}$ & \begin{tabular}{|l|}
$2 / 1.6$ \\
$1 / 4.6$
\end{tabular} & \begin{tabular}{|l|}
$1 / 1.6$ \\
$2 / 4.6$ \\
$6 / 5.6$ \\
$3 / 9.6$ \\
\end{tabular} & $6 / 15.6$ & & & & & & \\
\hline & 24 & & & & & & & & & & & & & & $2 / 10.6$ & \begin{tabular}{l|}
$2 / 1.6$ \\
$3 / 4.6$ \\
$1 / 10.6$ \\
$3 / 13.6$ \\
$8 / 14.6$
\end{tabular} & \begin{tabular}{|c|}
$1 / 1.6$ \\
$12 / 8.6$ \\
$13 / 14.6$
\end{tabular} & $6 / 10.6$ & & & & & \\
\hline & 25 & & & & & & & & & & & & & & $1 / 9.6$ & \begin{tabular}{l|}
$3 / 2.6$ \\
$2 / 3.6$ \\
$2 / 9.6$
\end{tabular} & \begin{tabular}{|l|}
$1 / 3.6$ \\
$5 / 7.6$ \\
$6 / 13.6$
\end{tabular} & $\begin{array}{l}4 / 7.6 \\
3 / 9.6 \\
3 / 13.6\end{array}$ & & & & & \\
\hline & 26 & & & & & & & & & & & & & & & & \begin{tabular}{l|}
$7 / 8.6$ \\
$3 / 12.6$
\end{tabular} & \begin{tabular}{|l|}
$5 / 8.6$ \\
$6 / 11.6$ \\
$3 / 12.6$
\end{tabular} & & & & & \\
\hline & 27 & & & & & & & & & & & & & & & $3 / 26.5$ & \begin{tabular}{|l|}
$2 / 1.6$ \\
$1 / 5.6$ \\
\end{tabular} & $\begin{array}{l}4 / 1.6 \\
8 / 5.6\end{array}$ & $1 / 7.6$ & & & & \\
\hline & & & & & & & & & & & & & & & & & & $\begin{array}{c}11 / 7.6 \\
9 / 11.6\end{array}$ & & & & & \\
\hline & 28 & & & & & & & & & & & & & & & $1 / 9.6$ & $2 / 9.6$ & \begin{tabular}{|c|}
$6 / 4.6$ \\
$6 / 6.6$ \\
$10 / 10.6$
\end{tabular} & $\begin{array}{c}5 / 10.6 \\
14 / 25.6\end{array}$ & $21 / 25.6$ & $7 / 25.6$ & & \\
\hline & 29 & & & & & & & & & & & & & & & & & \begin{tabular}{|r|}
$2 / 5.6$ \\
$10 / 8.6$ \\
$9 / 9.6$
\end{tabular} & $\begin{array}{l}1 / 5.6 \\
2 / 8.6 \\
9 / 9.6\end{array}$ & $18 / 21.6$ & $3 / 21.6$ & $1 / 21.6$ & \\
\hline & 30 & & & & & & & & & & & & & & & & $1 / 25.5$ & $\begin{array}{l}2 / 25.5 \\
9 / 2.6 \\
5 / 7.6 \\
6 / 8.6\end{array}$ & $\begin{array}{l}1 / 7.6 \\
7 / 8.6 \\
8 / 8.6\end{array}$ & $10 / 23.6$ & $4 / 23.6$ & & \\
\hline & 31 & & & & & & & & & & & & & & & & & $\begin{array}{l}3 / 1.6 \\
3 / 7.6\end{array}$ & $\begin{array}{l}3 / 1.6 \\
6 / 7.6\end{array}$ & $20 / 22.6$ & $27 / 22.6$ & & \\
\hline
\end{tabular}


\begin{tabular}{|l|l|l|}
\hline $1 / 29.6$ & $2 / 29.6$ & $3 / 25.6$ \\
\hline
\end{tabular}

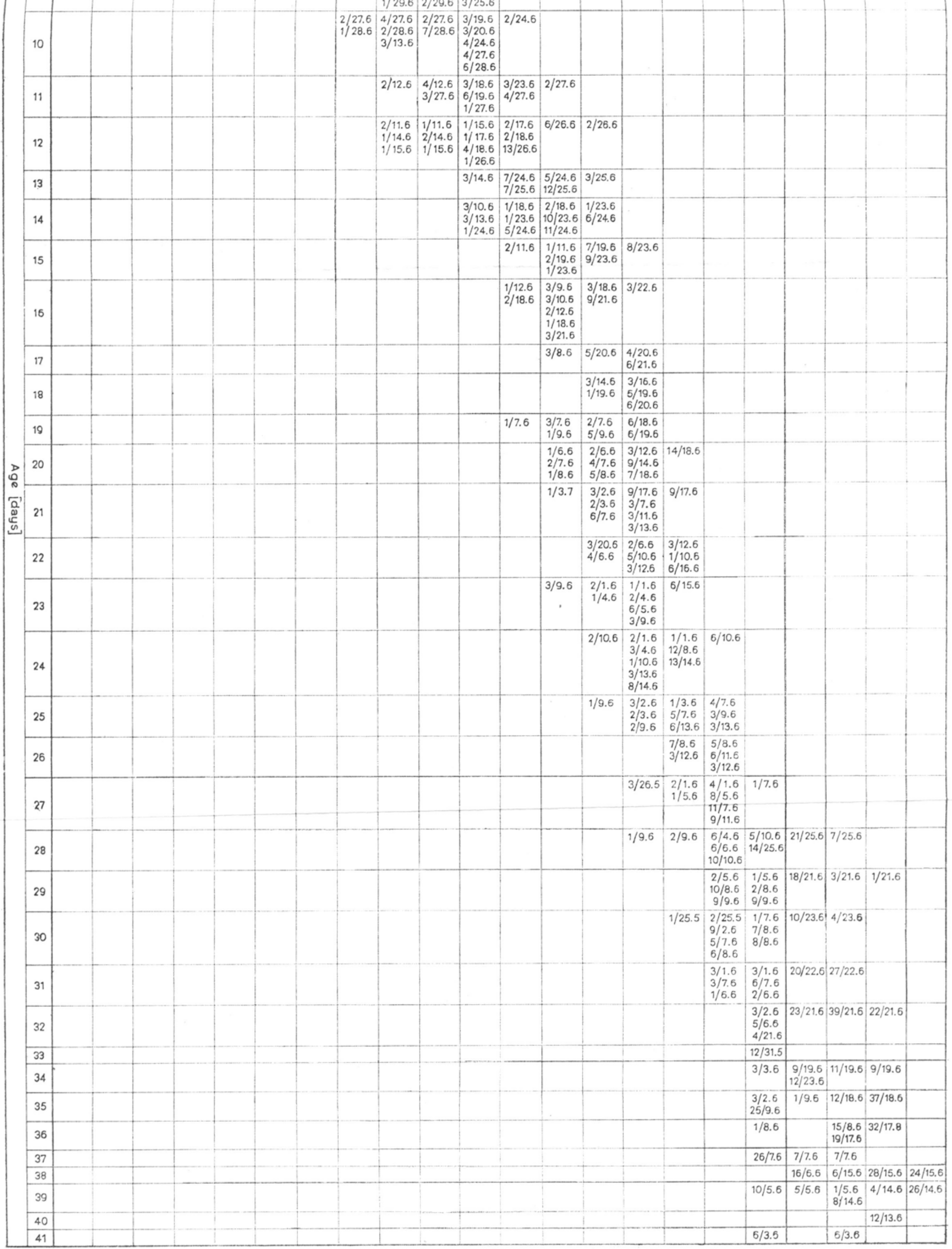




\section{RESULTS}

\section{PRESENTATION AND CRITICAL ANALYSiS OF DATA}

The results of all observations are listed in Table 1, with the number of embryos at given development stages for each age class and the dates of anthesis.

A total of 1468 embryos were examined, aged 2-41 days. In almost every sample of embryos of a given age there were individuals in different developmental stages beginning with, for instance, 12 days after anthesis, from late globular to older torpedo ones.

As seen from Table 1, it is possible to conclude when the given stages of embryo development appear and how long they last. These periods may be sometimes very long, for instance the torpedo stage occurred between day 12 and 25 after anthesis. In order to establish the causes of such wide differences in development, the meteorological conditions in which the embryos developed were analysed.

The mean diurnal temperatures, precipitation and relative humidity are shown in Fig. 1, and the number of embryos in various developmental stages observed at the successive dates is given in Table 2 .

Analysis of the meteorological data indicates the existence of three periods of different climatic conditions in which the embryos developed. The first comprising the days from May 25 to about June 17, 1976 was characterised by a rather low diurnal temperature within the range of $8-13^{\circ} \mathrm{C}$, a high humidity and the occurrence of rainfall. These con-

Table 1

Developmental stages of embryo abserved on successive days after anthesis in the course of the whole experiment. For each age of the embryo the nuniber of embryos observed in the given developmental stages and the dates of anthesis are given.

1c.-ca - proembryo with one-cell apical part ca; 2c.-ca - proembryo with two-cell apical part ca; quadr. - quadrant stage; oct. - octant stage; derm. 16-celled proembryo with differentiated dermatogen in layers 1 and 1'; I div first division of dermatogen or inner cells layer 1; per.-pl. - proembryo with differentiated periblem and plerome mother cells in layer l'; glob. 1 - younger globular embryo; glob. 2 - older globular embryo; trans. - transition stage; heart 1 - younger heart stage; heart 2 - older heart stage; torp. 1 - younge: torpedo stage; torp. 2 - older torpedo stage; inv. U - inverted U-shaped embryo; alm. dev. - almost fully developed embryos with cotyledons of the lenght as the embryo axis, but more delicate than older embryos, with thinner and less bent axis; green a - full grown maturing embryos, prepared out from 3till intensively green seeds; green b - maturing embryos from pale-green seeds; yell.-green - maturing embryos from yellowish-green seeds; br.-green - embryos from brownish-green seeds; brown - embryos from brown seeds; black - mature embryos from black seeds. 


\section{Table 2}

\begin{tabular}{|c|c|c|c|c|c|c|c|c|c|c|c|c|c|c|c|c|c|c|c|c|c|c|c|c|c|c|c|c|c|c|c|c|c|c|c|c|c|c|}
\hline black & & & & & & & & & & & & & & & & & & & & & 26 & 24 & & & & & & & & & & & & & & & & \\
\hline brown & & & & & & & & & & & & & & & & & & & & 12 & 4 & 28 & & 32 & 37 & 9 & & 23 & & & & & & & & & & \\
\hline br. green & & & & & & & & & & 6 & & 1 & & 7 & 15 & & & & & & 8 & 6. & & 19 & 12 & 11 & & 42 & 27 & 4 & & 7 & & & & & & \\
\hline yel.green & & & & & & & & & & & & 5 & 16 & 7 & & 1 & & & & & & & & & & 9 & & 41 & 20 & 22 & & 21 & & & & & & \\
\hline green b & & & & & & & 12 & 3 & 6 & 9 & & 11 & 7 & 34 & 18 & 34 & 5 & & & & & & & & & & & 4 & & & & 14 & & & & & & \\
\hline green a & 2 & & & & & & & 7 & 9 & & 6 & 10 & 7 & 23 & 21 & 12 & 16 & 15 & 3 & 3 & & & & & & & & & & & & & & & & & & \\
\hline alm. dev. & 1 & & & & & & & 3 & & 1 & & ? & & 5 & 19 & 2 & 1 & & 6 & 6 & 13 & 6 & 6 & 9 & 14 & & & & & & & & & & & & & \\
\hline inv. $U$ & & 3 & & & & & & 3 & 3 & 2 & 5 & 6 & 2 & 3 & & 6 & 6 & 3 & 6 & 6 & 17 & & 3 & 9 & 13 & 11 & 10 & 6 & 3 & 8 & & & & & & & & \\
\hline torp. 2 & & & & & & & & 2 & 6 & 2 & 1 & & 6 & 12 & 5 & 6 & 2 & & & & 3 & 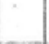 & & & 3 & 8 & 5 & 9 & & 10 & 6 & 3 & 2 & & & & & \\
\hline torp. 1 & & & & & & & & & & 1 & & & 1 & 5 & 4 & 7 & 3 & 1 & 2 & & & & & & 3 & 2 & & 3 & & 11 & 16 & 12 & 6 & 2 & & & & \\
\hline heart 2 & & & & & & & & & & & & & & 1 & & & & 2 & 1 & & & & & 2 & 5 & & & & & 4 & 14 & 7 & 13 & 4 & & & & \\
\hline heart 1 & & & & 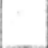 & & & & & & & & & & & & & 3 & & & 3 & 3 & 1 & & 1 & 7 & 9 & 4 & 1 & 3 & & 5 & 3 & 1 & 5 & 6 & & & \\
\hline trans. & & - & & & & & . & & & & . & & & & & & & 1 & 4 & & 2 & 1 & & & & & & 4 & 2 & 6 & & & 3 & 5 & 7 & 2 & & \\
\hline glob. 2 & & & & & & & & & & & & & & & 1 & & & 2 & 2 & 3 & 1 & 3 & & & & & & 3 & 1 & 5 & & & 2 & 4 & 2 & 1 & 3 & \\
\hline glob. 1 & & & & & & & & & & & & & & & & . & & & & & & 3 & & & 5 & 2 & & 5 & 1 & & 3 & i & & 2 & 1 & & 3 & \\
\hline per:- p!. & & & & & & & & & & & & & & & 8 & & & & & & & 3 & & & & 1 & 1 & 2 & 1 & 1 & 4 & & & & & & & \\
\hline I div. & & & & & & & & & & & & & & & 1 & & & & & & & 1 & & & 1 & & 1 & & 1 & 1 & 2 & 2 & & & 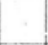 & & & \\
\hline derm. & & & & & & & & & & & & & & & & & & & & & & & & & & & & 1 & 3 & 2 & & 4 & & & $\therefore$ & & & \\
\hline octant & & & & . & & & & & & & & & & & & & & & & & & & & & & & 1 & 3 & 2 & . & 11 & 4 & & & .. & & & \\
\hline quadr. & & & & & & & & & & & & & & & & & & & & & & & & & & & & 1 & 1 & & & 1 & 1 & 3 & 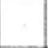 & & & 3 \\
\hline $2 \mathrm{c}-\mathrm{ca}$ & & & & & & & & & & & & & & & & & & & & & & & & f & & & & 1 & & & & & & 1 & & & & 1 \\
\hline $1 \mathrm{c}-\mathrm{ca}$ & & & & & 2 & & & & & & & & & & & & & & & & & & & & & & & & & 1 & & & & & & & & \\
\hline Sta & $25 . \mathrm{V}$ & 25 & 27 & 28 & 29 & 30 & 31 & $1 . \mathrm{VI}$ & 2 & 3 & 4 & 5 & 6 & 7 & 8 & 9 & 10 & 11 & 12 & 13 & 14 & 15 & 16 & 17 & 18 & 19 & 20 & 21 & 22 & 23 & 24 & 25 & 26 & 27 & 28 & 29 & 30 & 1.VII \\
\hline
\end{tabular}

Number of embryos in various development stages observed after anthesis in successive days between May 25 and July 1 , 1976. For stage abbreviations see the explanations of Table 1. 
ditions prolonged the developmental processes. The second period from June 20 to about July 8 was a period of high diurnal temperatures (of the order of $20^{\circ} \mathrm{C}$ ), low humidity and no precipitation. The embryos of plants flowering in this period developed rapidly from the beginning. Since this period lasted rather long (about 20 days) a group of embryos from the beginning of this period, that is from flowers unfolding between June 20 and 25 were chosen for establishing the time relations in rape embryo development. The third period from July 8 to 25 was warm (mean diurnal temperature of the order of $20^{\circ} \mathrm{C}$ ) and humid. It fell to the time of rape harvest and its character did not interfere in any major way with the development of embryos from plants flowering in the period chosen for characterisation of their development.

The influence of climatic conditions on rape embryo development is shown in Fig. 2 which illustrates the development of embryos after anthesis at 3 different dates corresponding to different atmospheric periods. These embryo samples were collected after anthesis on June 2, 15 and 25. The growth of the embryos occurred in these samples similarly, but the curve indicates a different time necessary for reaching a definite developmental stage. The embryos of June 2 under least favourable atmospheric conditions (very low temperatures for the first two weeks) developed longest. Most rapidly developed the embryos from flowers opening on June 25, growing at first under dry conditions with high mean diurnal temperatures.

It results from Table 2 that in the group of embryos from flowers opening between June 20 and 25 nearly all developmental stages are present (almost fully developed and green ones excepted).

These data (June 20-25) are shown in Table 3. In it the number of embryos in various stages and the frequency of their occurrence in per cents are given for all ages, and for each stage its frequency in the successive days of its occurrence is recorded.

On the basis of these data the mean age of the embryo was calculated for nearly all stages, according to the formula given in the Methods. The age of embryos in stage 16 (last stage of embryogenesis) and 17 (full grown embryos from green seeds a) were graphically determined by interpolation (Table 3 ). The age of the embryos in all 3 first stages was calculated on the basis of all observations referring to these stages. The mean time of occurrence of the further two stages (4th and 5th) calculated in the same way was identical with the time calculated on the basis of samples from the period between June 20 to 25. Therefore, the data for the first 3 stages can be considered as reliable.

With data available on the time of occurrence of the successive developmental stages of the embryo and information on the dimensions 


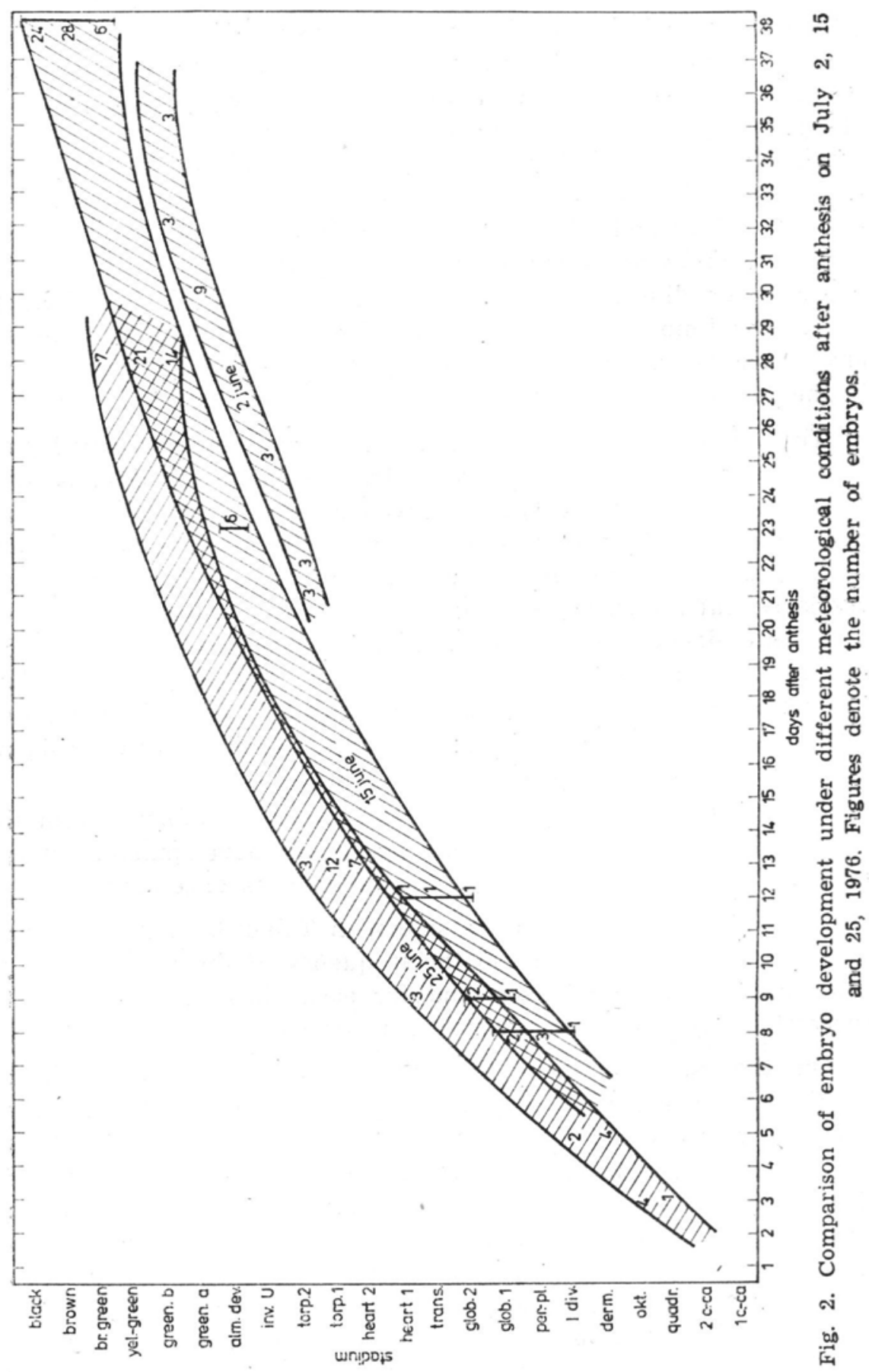


Table 3

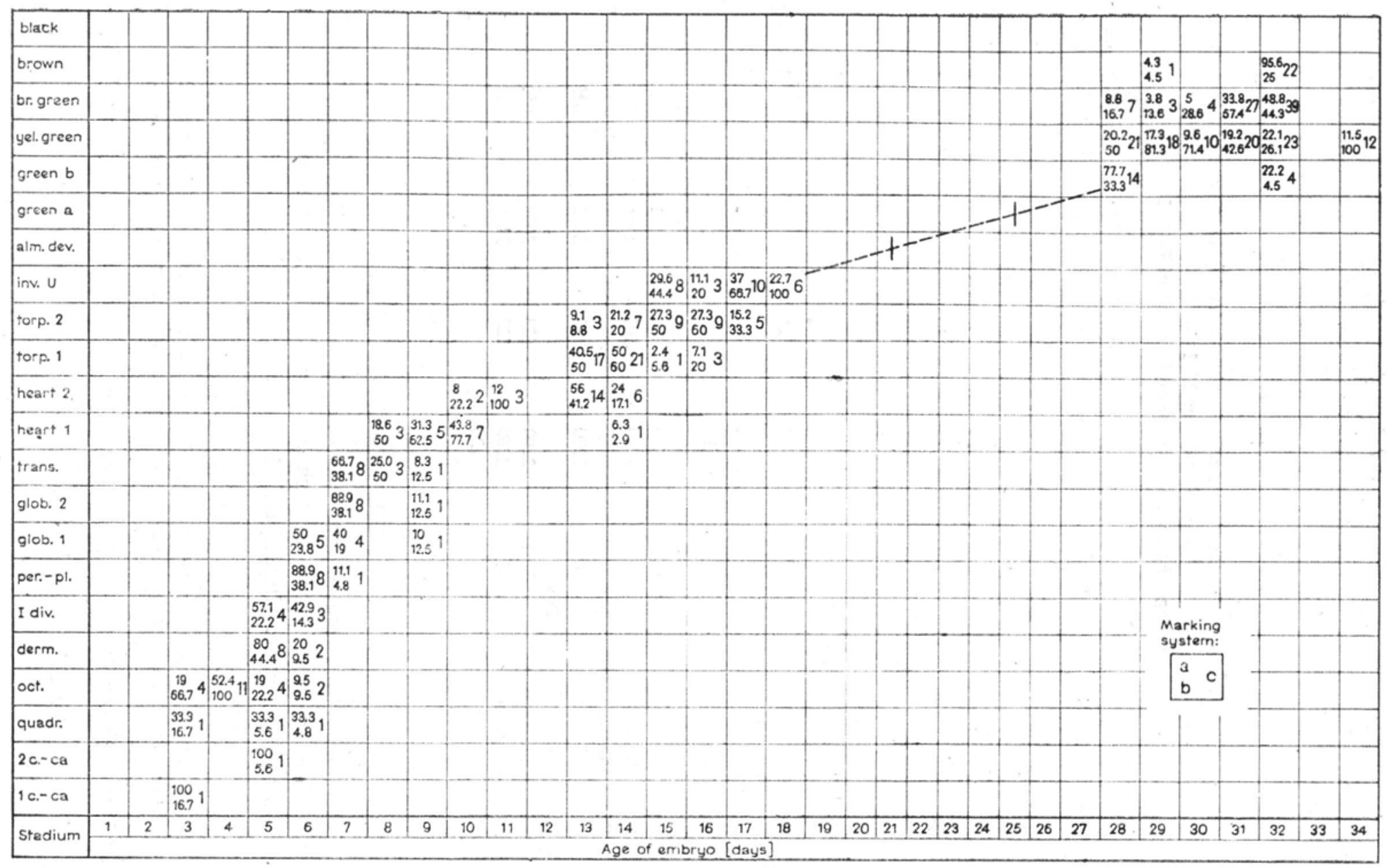

Explanations on page 378 . 
of the embryo axis for all stages (taken from the preceding paper, Ty$\mathrm{k}$ a r s k a, 1979) - Table 4, the growth curves of the embryo axis were plotted (Figs 3 and 4).

\section{Table 4}

Mean age and dimensions of successive stages of embryos developing after anthesis between June 20 and June 25, 1976

For stage abbreviations see the explanations of Table 1

\begin{tabular}{|c|c|c|c|c|c|c|}
\hline \multirow[b]{2}{*}{ No. } & \multirow[b]{2}{*}{ Stage } & \multirow[b]{2}{*}{ Age (days) } & \multicolumn{3}{|c|}{ Length of embryo layers $(\mu \mathrm{m})$} & \multirow{2}{*}{$\begin{array}{l}\text { Width of em- } \\
\text { bryo axis at leve } \\
\text { of } O \text { 'border }(\mu \mathrm{m}\end{array}$} \\
\hline & & & $l+l^{\prime}$ & $l$ & $l^{\prime}$ & \\
\hline 1. & 1 -c.ca & 2.3 & 6.1 & & & \\
\hline 2. & $2-c . c a$ & 3.3 & 13.8 & & & 15.3 \\
\hline 3. & quadr. & 3.6 & 16 & & & 18.1 \\
\hline 4. & oct. & 4.2 & 17.5 & 10.3 & 7.2 & 21.6 \\
\hline 5. & derm. & 5.2 & 20 & 11.6 & 8.4 & 27 \\
\hline 6. & I div. & 5.4 & 21 & 13.3 & 7.7 & 30 \\
\hline 7. & per.-pl. & 6.1 & 27 & 16.1 & 10.9 & 36.3 \\
\hline 8. & glob. 1 & 6.7 & 36.7 & 18.5 & 18.3 & 49.1 \\
\hline 9. & glob. 2 & 7.2 & 55.9 & 23.6 & 32.1 & 65.6 \\
\hline 10. & trans. & 7.4 & 77.5 & 26.6 & 50.9 & 87.3 \\
\hline 11. & heart 1 & 9.6 & 93.5 & 27.2 & 66.2 & 118 \\
\hline 12. & heart 2 & 12.8 & 167 & 30.4 & 137 & 146 \\
\hline 13. & torp. 1 & 13.8 & 311 & 37.5 & 274 & 162 \\
\hline 14. & torp. 2 & 15.2 & 468 & 44.3 & 423.4 & 187 \\
\hline 15. & inv. $U$ & 16.5 & 839 & 47.6 & 791 & 222 \\
\hline 16. & alm. dev. & 20.9 & 1990 & 101 & 1888 & 500 \\
\hline 17. & gieen $a$ & 24.9 & & & & \\
\hline & & 26.9 & 2200 & 117 & 2082 & 635 \\
\hline 18. & grcen $b$ & 28.9 & & & & \\
\hline 19. & yell.-green & 30.2 & 2200 & 123 & 2078 & 650 \\
\hline 20. & br.-green & 31.2 & 2260 & 123 & 2140 & 660 \\
\hline 21. & brown & & 2220 & & & \\
\hline 22. & black & & 2300 & & & \\
\hline
\end{tabular}

2. GROWTH OF EMBRYO AXIS

The growth curve of the whole embryo axis plotted in arithmetic scale has an almost sigmoidal shape (Fig. 3). Three partly overlapping segments can be distinguished in it, each of which is also sigmoidal.

\section{Table 3}

List of data concerning development of embryos after anthesis between June 20 and June 25, 1976. For each stage the number of embryos observed (c) is given and the frequency of occurrence of the given stage $(\%)$ on successive days (a) and for each age its frequency of occurrence $(\%)$ is recorded in various developmental stages of the embryo (b)

For stage abbreviations see the explanations of Table 1. 
The growth curve of the rape embryo axis may be thus defined as triple-sigmoidal.

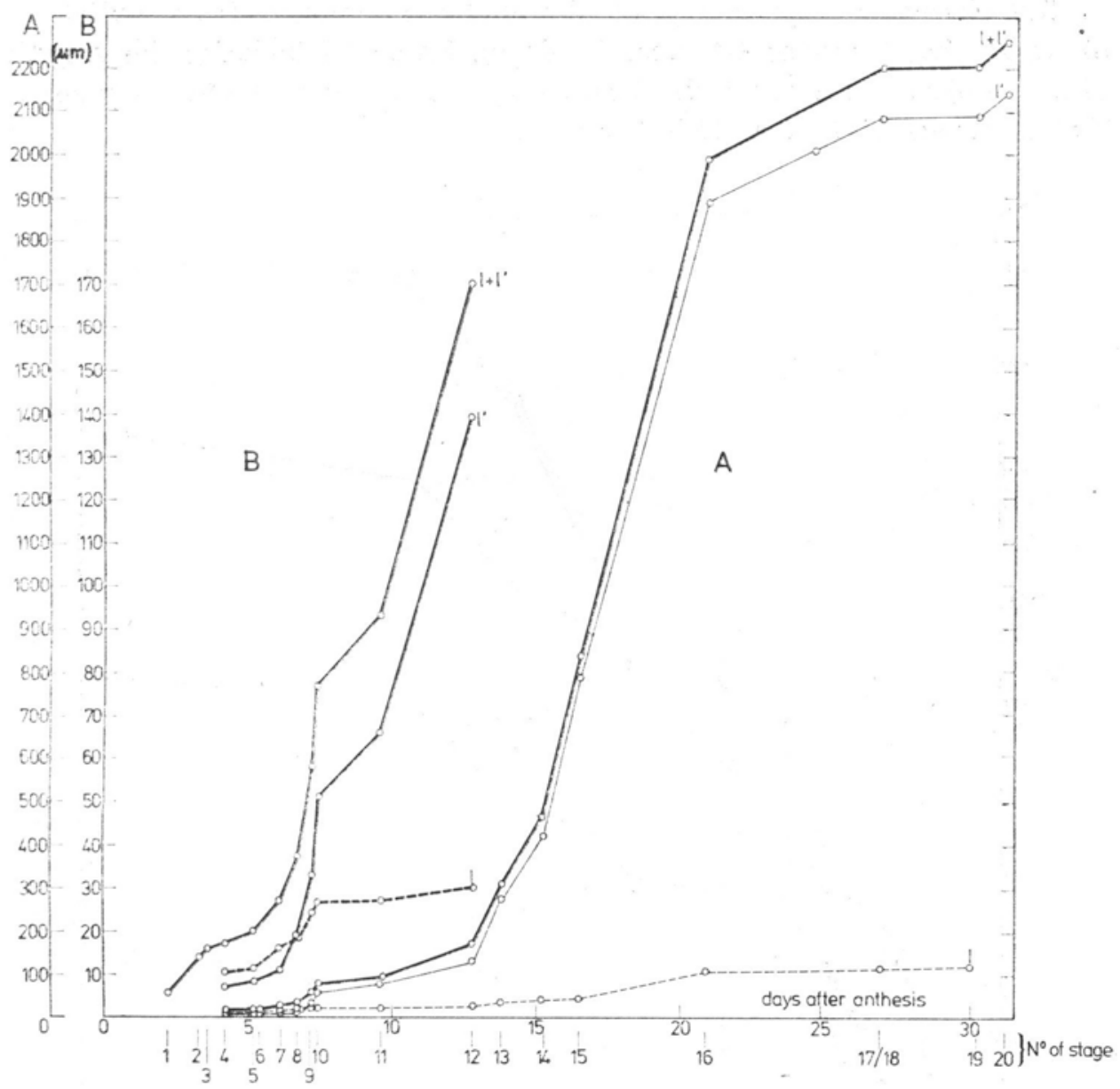

Fig. 3. A - Growth curves of embryo axis length $\left(1+1^{\prime}\right)$ and of 1 and $l^{\prime}$ embryo layers. Data for embryos developing after anthesis in the period between June 20 and $25,1976, \mathrm{~B}-$ beginning of the same curves in a $10: 2$ scale

No of stage means: 1. - proembryo with one-cell apical part ca; 2. - proembryo with two-cell apical part ca; 3. - quadrant stage; 4. - octant stage; 5. - 16-celled proembryo with differentiated dermatogen in layers 1 and $1^{\prime}$; 6 . - first division of dermatogen or inner cells layer $1 ; 7$. - proembryo with differentiated periblem and plerome mother cells in layer 1'; 8. - younger globular embryo; 9. - older globular embryo; 10. - transition stage; 11. - younger heart stage; 12. - older heart stage; 13. - younger torpedo stage; 14. - older torpedo stage; 15. - inverted U-shaped embryo; 16. - almost fully developed embryos with cotyledons of the length as the embryo axis, but more delicate then older embryos, with thinner and less bent axis; 17. - full grown maturing embryos, prepared out from still intensively green seeds; 18. - maturing embryos from pale-green seeds; 19. maturing embryos from yellowish-green seeds; 20. - embryos from brownish-green seeds; 21. - embryos from brown seeds; 22. - mature embryos from black seeds

To the three components of the growth curve of the embryo axis correspond three phases of embryo growth. Phase I includes the growth 
of the apical cell to its division into two layers of octants, that is stages 1-4 (ca. 2 days). Phase II comprises growth of the spherical proembryo to the change of symmetry of the globular embryo from radial to bilateral, that is stages 4-11 (ca. 5.5 days). Phase III includes the growth of the embryo axis from the heart stage to the end of embryogenesis, that is stages 11-17 (ca. 15.5 days).

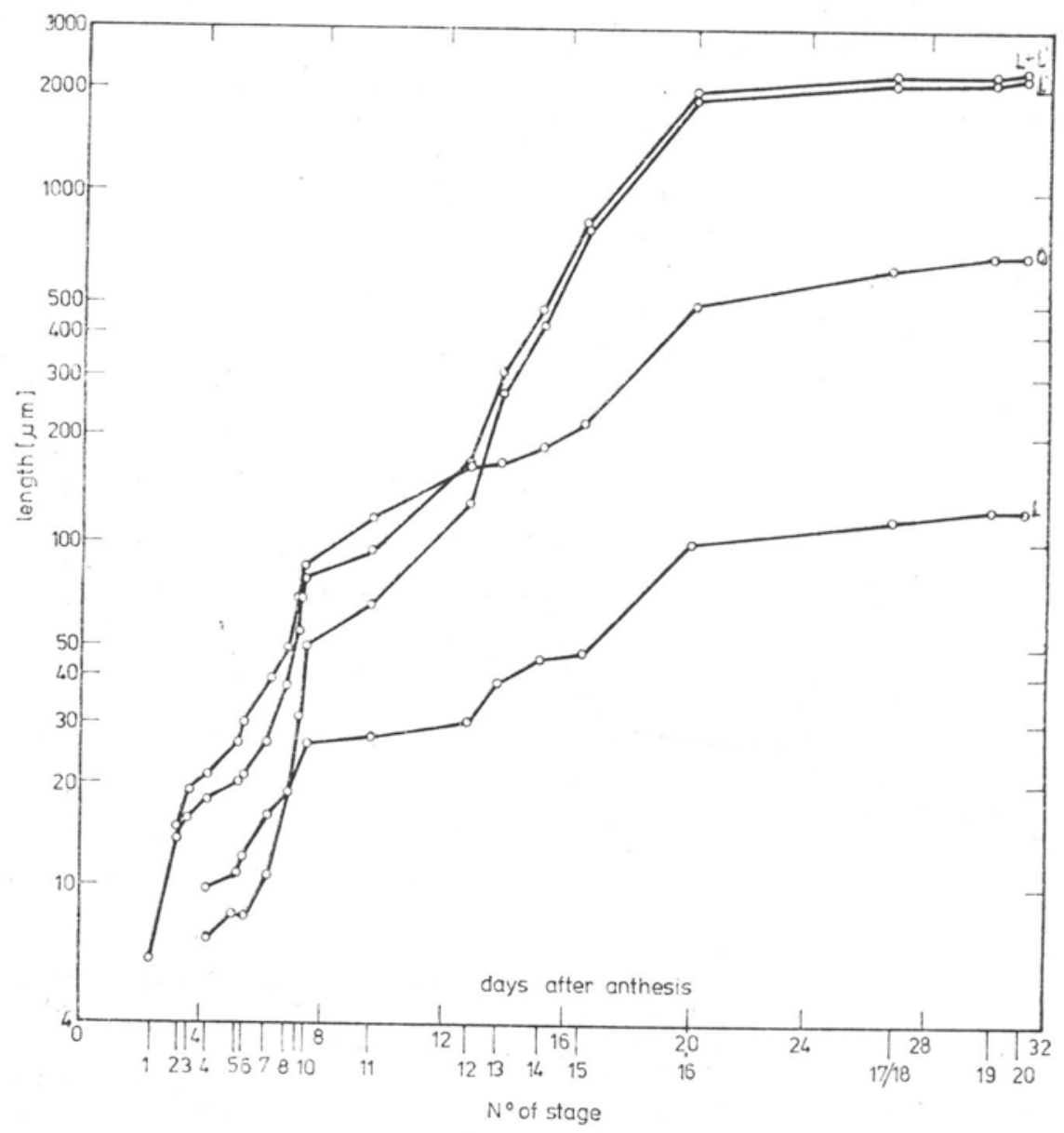

Fig. 4. Growth curves of length $\left(1+1^{\prime}\right)$ and width $\left(0^{\prime}\right)$ of embryo axis and length of embryo layers 1 and $l^{\prime}$ plotted in logarithmic scale

For stage abbreviations see the explanations of Fig. 3

The same three growth phases can be distinguished on the growth curves of axis length and width plotted in logarithmic scale (Fig. 4). In each phase the relative rate of growth, which is the best measure of growth intensity, increases drastically and then declines. The differences in growth intensity during the same phase may be tenfold or even 
larger, for instance at the beginning of phase II between stages 4 and 5 the relative growth rate is $14 \%$ per day, and the maximal growth rate in this phase, between stages 8 and 10 is $159 \%$ per day (Table 5).

The embryo axis elongated most intensively at maximal growth rate by 159 per cent per day in phase II of growth in a time of about $17 \mathrm{~h}$ between stages 8 and 10, that is in the globular embryo. The apical cell elongates almosit as intensively, at a maximal rate of $126 \%$ per day in phase I of growth in the course of $24 \mathrm{~h}$ between stage 1 and 2 . The

Table 5

Maximal and minimal growth intensity in the 3 phase of embryo axis growth

For stage abbreviations see the explanations of Table 1 and Fig. 3

\begin{tabular}{|c|c|c|c|c|c|c|}
\hline \multirow{2}{*}{\multicolumn{2}{|c|}{ Growth steps }} & \multirow{2}{*}{$\begin{array}{l}\text { Duration } \\
\text { of step } \\
\text { (days) }\end{array}$} & \multicolumn{2}{|c|}{$\begin{array}{c}\text { Relative growth rate } \\
(\% \text { day })\end{array}$} & \multicolumn{2}{|c|}{ Doubling time of length } \\
\hline & & & $l+l^{\prime}$ & $l^{\prime}$ & $l+l^{\prime}$ & $l^{\prime}$ \\
\hline 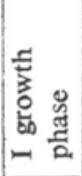 & $\begin{array}{l}\text { 1-2 cells } c a \\
\text { (1-2 stage) } \\
\text { quadr.-oct. } \\
\text { (3-4 stage) }\end{array}$ & 1.0 & $\begin{array}{r}126.2 \\
15.6\end{array}$ & - & $\begin{array}{l}0.8 \text { day }= \\
=19 \text { hours } \\
6.4 \text { days }\end{array}$ & \\
\hline 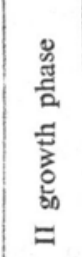 & $\begin{array}{l}\text { octants-dermat. } \\
\text { different. ( } 4-5 \text { stage) } \\
\text { glob. } 1 \text {-trans. } \\
\text { (8-10 stage) } \\
\text { trans.-heart } 1 \\
\text { (10-11 stage) }\end{array}$ & 0.7 & 158.8 & $\begin{array}{r}16.7 \\
253.6 \\
13.7\end{array}$ & $\begin{array}{l}7 \text { days } \\
0.63 \text { days }= \\
=15.1 \text { hours } \\
10.6 \text { days }\end{array}$ & $\begin{array}{c}6 \text { days } \\
0.4 \text { day }= \\
=9.5 \text { hours } \\
7.3 \text { days }\end{array}$ \\
\hline 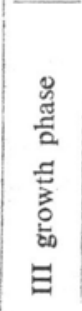 & $\begin{array}{l}\text { heart 1-heart } 2 \\
\text { (11-12 staga) } \\
\text { heart 2-inv. U } \\
\text { (12-15 stage) } \\
\text { alm. dev.-maturing } \\
\text { from green seeds } \\
\text { (16-17/18 stage) }\end{array}$ & 3.7 & 108.8 & 33.4 & $\begin{array}{c}\quad 4.1 \text { days } \\
0.92 \text { day }= \\
=22 \text { hours } \\
57 \text { days }\end{array}$ & $\begin{array}{l}3 \text { days } \\
0.78 \text { day }= \\
=18.6 \text { hours } \\
\\
58.5 \text { days }\end{array}$ \\
\hline
\end{tabular}

intensity of axis elongation in growth phase III is the lowest. The maximal growth rate in this phase occurring for 4 days during development of the torpedo-shaped embryo is $109 \%$ per day (Table 5).

In the period of rapid growth of the torpedo embryo the rate of elongation of the axis transiently diminishes for a short time, this coinciding with the bending of the cotyledons and of the apical part of the embryo axis. The relative growth rate of $l+l^{\prime}$ is in the sucessive steps of this period 80,36 and $61 \%$ per day. 


\section{GROW'TH OF EMBRYO LAYERS $l$ AND $l^{\prime}$}

The growth curves of layers $l$ and $l^{\prime}$ are presented in arithmetic scale in Fig. 3 and in logarithmic scale in Fig. 4, the relative rate of growth of both layers is shown in Table 4 and in the diagram (Fig. 5).

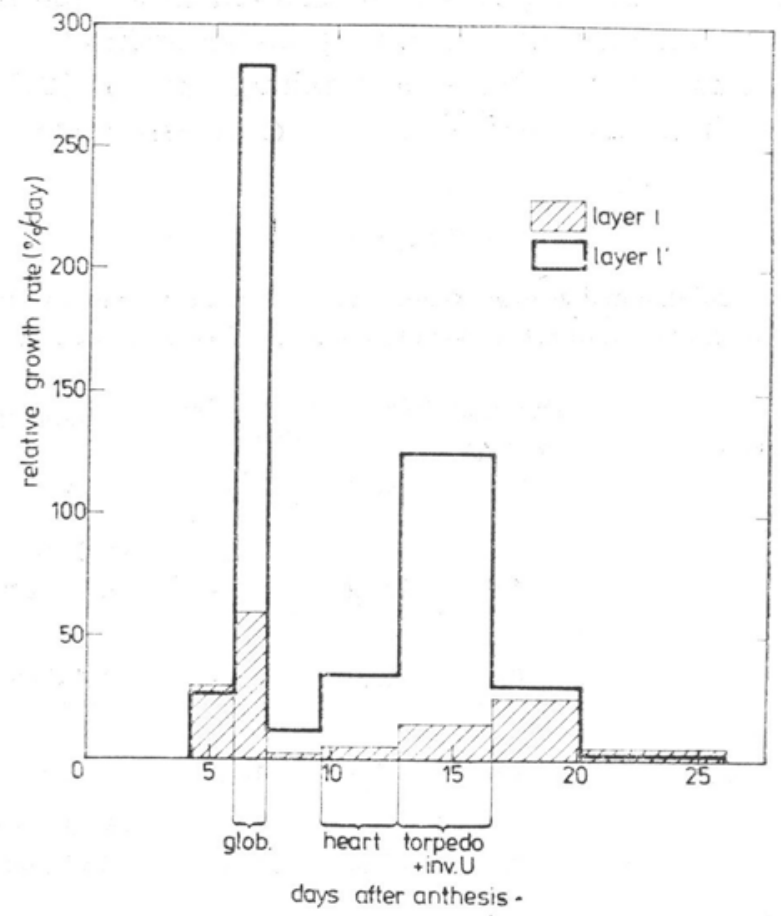

Fig. 5. Relative growth rate of layers 1 and $l^{\prime}$ in period from octant stage to the end of embryogenesis.

glob - globular stage, heart - heart stage, torp.+inv. U - torpedo+inverted U-shaped stage

Growth of both layers occurs in two phases corresponding to phases II and III of embryo growth (Fig. 5). In phase II the course of growth of both layers is similar. They reach maximal growth rate at the stage of globular embryo, but the growth intensity of layer $l^{\prime}$ is higher. In phase III growth of both layers has a different course. In layer $l$ the relative growth intensity is not high, increasing gradually it reaches maximum in the last stage of embryogenesis at the time of development of the shoot apical meristem. In layer $l^{\prime}$ the relative growth rate is much higher the whole time. Maximum occurs in the period of meristematic division growth of the hypocotyl and radicle at the time of development of the torpedo embryo (Table 6, Fig. 5).

The contribution of layer $l^{\prime}$ to the growth of the axis is dominant, therefore the course of growth of whole embryo axis is very similar to that of layer $l^{\prime}$. 
Table 6

Relative growth rate of layers $l$ and $l^{\prime}$

For stage abbreviations see the explanations of Table 1 and Fig. 3

\begin{tabular}{|c|c|c|c|c|}
\hline & \multirow[t]{2}{*}{ Step of embryogenesis } & \multirow{2}{*}{$\begin{array}{l}\text { Duration of } \\
\text { step (days) }\end{array}$} & \multicolumn{2}{|c|}{$\begin{array}{c}\text { Relative growth rate } \\
\text { (\% day) }\end{array}$} \\
\hline & & & layer $l$ & layer $l^{\prime}$ \\
\hline 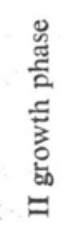 & $\begin{array}{l}\text { octants-different of per.-pl. } \\
\text { (4-7 stage) } \\
\text { per.-pl.-trans. } \\
\text { (7-10 stage) } \\
\text { trans.-heart } 1 \\
\text { (10-11 stage) }\end{array}$ & $\begin{array}{l}1.9 \\
1.3 \\
\\
2.2\end{array}$ & $\begin{array}{r}29.6 \\
50.2 \\
1.03\end{array}$ & $\begin{array}{r}27.0 \\
282.3 \\
13.7\end{array}$ \\
\hline 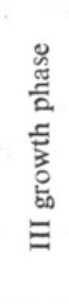 & $\begin{array}{l}\text { heart 1-heart } 2 \\
\text { (11-12 stage) } \\
\text { heart 2-inv. U } \\
(12-15 \text { stage) } \\
\text { inv. U-alm. dev. } \\
\text { (15-16 stage) } \\
\text { alm.dev.-maturing from green seed } \\
(16-17 / 18 \text { stage) }\end{array}$ & $\begin{array}{l}3.2 \\
3.7 \\
4.4 \\
6.0\end{array}$ & $\begin{array}{r}3.7 \\
15.3 \\
25.5 \\
2.6\end{array}$ & $\begin{array}{r}33.4 \\
129.0 \\
31.5 \\
1.7\end{array}$ \\
\hline
\end{tabular}

After the end of embryogenesis the axis elongates further; however, owing to the insufficient number of observations and measurements, it is difficult to establish the course of the growth curve in this period. It is doubtless, nevertheless, that at the time of decline of growth of layer $l^{\prime}$, that is of the hypocotyl and radicle, layer $l$ containing the shoot primordium continues to grow (Table 6).

\section{DISCUSSION}

In the previous papers ( $\mathrm{Tyk}$ a r s a $, 1976,1979$ ) the course of rape embryogenesis has been described with distinction of the successive developmental stages, and the mean dimensions of the embryo in each stage were determined. In the present paper the mean age of the embryo was established in these stages by calculating it on the basis of the frequency of occurrence of these stages on the successive days after anthesis. Since the age and dimensions of the embryo were known, growth curves were plotted for the embryo axis and the relative growth rate $(\%$ per day) was calculated as the measure of growth intensity.

The overall growth curve of the rape embryo has an almost sigmoid shape. It consists of 3 partly overlapping sigmoid segments corresponding to 3 growth phases of the embryo.

Phase I of growth of the embryo proper comprises the growth of the apical cell up to its division into two layers of octants, phase II 
includes the growth of the spherical proembryo and globular embryo to the initiation of cotyledons and phase III involves the development of the heart-shaped to the full grown embryo. The peaks of growth intensity coincide with the period of elongation of the apical cell before its division and with the period of cell division growth in the globular and torpedo-shaped embryos.

The intensity of growth of the embryo axis is highest during development of the globular embryo, and its height doubles then within about 9 h. Changes in growth intensity of the embryo axis are probably correlated with the development of other embryo parts. The decline of growth of the apical part of the proembryo after the first peak may be due to the rapid growth of the suspensor. The depression in growth intensity of the embryo axis in mid embryogenesis coincides with the initiation of cotyledons.

The exponential growth of the torpedo-shaped embryo is correlated with the doubling of the cell number in the axis by anticlinal divisions (T y k a r s a, 1979).

The growth of the embryo axis as a whole is a result of the growth of the two component parts, embryo layers $l$ and $l^{\prime}$. These layers grow quite differently, but in both their curves of growth phases II and III are easily distinguishable. The same growth phases appear at the same time also in the course of the growth curve of the embryo axis width.

There is, therefore, no doubt that the three phases of embryo growth correspond to three different periods of embryo development. In the first period the undifferentiated globular proembryo arises, in the second the globular proembryo develops and transforms to the embryo proper with primordia of all the organs, in the third period the organs of the embryo develop.

The sigmoid shape of the growth curve is typical for fruits and seeds. Such is, for instance the growth curve of rape siliques (N or ton, 1975) and of bean pods (W a $1 \mathrm{~b}$ ot et al., 1972).

The reserve material accumulation in seeds, for instance the amount of erucic acid in rape seeds (F o w ler, 1970), of phytic acid in bean (Keith, Walker, 1974) and the dry mass increase in rape seeds (F ow le r, 1970) also follow a sigmoid growth curve.

Precise data are lacking in the literature on the development of embryos in time. Usually the embryo growth can be represented by a simple sigmoidal curve. That is how for instance the whole length of the embryo with cotyledons increases in Capsella ( $\mathrm{R} \mathrm{i} \mathrm{jve} \mathrm{n,} \mathrm{1952).} \mathrm{But}$ the growth curve of fresh mass of the bean embryo axis has a double sigmoid shape. In this case the decline of axis growth intensity falls to the period of fastest increase of the fresh mass of the cotyledons (W a lbot et al., 1972). 


\title{
Acknowledgments
}

The author is deeply indebted to Professor Henryk Teleżyński for his keen and critical analysis of results of her investigations and for guidance in their interpretation.

\section{REFERENCES}

Fow le r D. B., Downey R. K., 1970. Lipid and morphological changes in developing rape seed, Brassica napus. Can. J. Plant Sci. 50: 233-247.

Keith A., Walker, 1974. Changes in phytic acid and phytase during early development of Phaseolus vulgaris L. Planta 116: 91-98.

Norton G., Harris J. F., 1975. Compositional changes in developing rape seed (Brassica napus L.). Planta 123: 163-174.

Rijven A. H., 1952. In vitro studies on the embryo of Capsella bursa-pastoris. Acta Bot. Neederl. 1: 157-200.

Tykarska T., 1976. Rape embryogenesis. I. The proembryo development. Acta Soc. Bot. Pol. 45: 3-16.

Tykarska T., 1979. Rape embryogenesis. II. Development of embryo proper. Acta Soc. Bot. Pol. 48: 391-422.

W a 1 b ot V., C l ut ter M., S u s s ex J. M., 1972. Reproductive development and embryogeny in Phaseolus. Phytomorphology 22: 59-68.

\section{Embriogeneza rzepaku. III. Przebieg rozwoju zarodka $w$ czasie}

\author{
Streszczenie
}

Stwierdzono, że krzywa wzrostu osi zarodka rzepaku jest potrójnie sigmoidalna. Wzrost zarodka przebiega $w$ trzech fazach, odpowiadających trzem różnym okresom rozwoju zarodka. I faza obejmuje wzrost komórki apikalnej do podziału jej na dwa piętra oktantów. II faza obejmuje wzrost kulistego prazarodka do zmiany symetrii globularnego zarodka z promienistej na bilateralną. III faza obejmuje wzrost osi sercowatego i torpedowatego zarodka aż do calkowitego zakończenia embriogenezy. W każdej fazie względna szybkość wzrostu wzmaga się gwaltownie a potem opada. Różnice intensywności wzrostu w czasie tej samej fazy są co najmniej kilkakrotne a mogą być dziesięciokrotne lub nawet większe. Największa intensywność wzrostu osi zarodka występuje w fazie II. Maksimum intensywności wzrostu przypada w I fazie na okres wydłużania się komórki apikalnej przed jej podziałem. II i III maksimum występuje w okresie merystematycznego wzrostu podziałowego $\mathrm{w}$ globularnym i torpedowatym zarodku. Zmiany szybkości wzrostu osi zarodka są prawdopodobnie następstwem korelacyjnych oddziaływań rozwojowych. Osłabienie wzrostu apikalnej części prazarodka po I maksimum jest prawdopodobnie następstwem szybkiego wzrostu suspensora. Zahamowanie wzrostu osi w środku embriogenezy związane jest z inicjacją liścieni. 